culated over the whole yoar was a little lower than that for 1960. These figures are reassuring, but the full effects of the woapons trials on strontium-90 levels in milk are not expectod to be apparent until the results for the summer of 1962 are available. For the average mixed diet of the wholo population, the strontium-90 levol during 1961 was about $6 \cdot 1$ picocuries of strontium- 90 per gram of calcium. This value is similar to that of 1960 and lower than that of 1959 .

\section{The Lace Research Association}

THE thirteenth annual report of the Lace Resoarch Association covers the year 1961 (Pp. 35. Bilborough, Nottingham: The Lace Research Association, 1962). In the account of the progress of research, it is noted that production of cellular cotton blankots for hospital use has now reached an advanced stage of development, and it is considered that a similar blanket structure made from an acrylic yarn might be more suitable for the domestic market. $\Lambda$ successful technique has been devisod for producing tubular nots on the furnishings machine, while the problem of winding an increased length of usable yarn into the Leavers machine, in which the brass bobbins carrying the binding thread of the lace structure are spread between 8 and 30 per inch, is being tackled. This is being done by investigating tho use of special nylon yarns of fine count and extra strength, by radically improving the machinery for winding the yarn into the bobbins and by examining the processos of heating and pressing the bobbins after winding. The new 'Lacra' bobbin winders have fulfilled in production all the claims made for them; fundamental work on the heating and pressing of brass bobbins continues. The new beam thread-break indicator has also given satisfactory results on a production scale. The Association has assessed the potentialities of the now high-speed lace machine designed by Dr. McGallion and Prof. Pope of the University of Nottingham. Two of the major projects of the year were concerned with the mechanical removal of floats from lace and the treatment of lace to give low flammability.

\section{The Rubber Research Institute of Ceylon}

THe rubber industry of Ceylon, though small compared with that of Malaya, is nevertheless of vital importance to the country's economy, as it was to Great Britain and her allies during a critical phase of the Second World War. It is interesting to recall that it was in Ceylon in 1876 that the plantation industry was born-from plants nurtured at Kewthough it was not until the present century that plantation rubber began to oust native Brazilian rubber as the primary commodity of commerce. The place of science in the subsequent development of the industry is recognized in a booklet issued on the occasion of the fiftieth anniversary of the foundation of the Rubber Research Schome-the forerunner of the present Rubber Research Institute of Ceylon-to which leading members of the Government and of the industry have contributed (Rubber Research Institute of Ceylon. Golden Jubilee, 1910-1960. Pp. xviii +14. Dartonfield, Agalawatta: Rubber Research Institute of Ceylon, 1961). In the face of intenso competition from the synthetics, the plantation industry depends for its survival on the reduction of costs and improvement of quality which can only be brought about by the fullest exploitation of scientific knowledge and scientific methods. Factors of major importance are the replacement of older and inefficient troes with newly developed high-yiclding types, the effective control of disoase, and good husbandry and estate management. In all these aspects the Institute's scientific and advisory staff, working within a frame-work of Govornmont assistance, has played an indispensable part, particularly in relation to the small-holders.

\section{Research into Urban 'Decay'}

ThE June Newsletter of the Manchester Joint Research Council Technical Information Centre, besides notes on some inquiries handled in May, includes a note by Mr. F. Medhurst, director of the Research Group of the North West Civic Trust, on research into urban 'decay', which touches on some aspects of his task. Tho Research Group, which hopes to discover the obstacles to improving the general environment of the mixed areas around city centres, will study land and property values, investment-lovels, public transport services, changes in land uses and obsolescence factors for clues to the causes of urban decay. The study is planned to continue over three years, and an ondeavour will be made activoly to improve a selected area as an experiment in methods and techniquos. The Research Group will welcome the suggestions and co-operation of any who are interested in the problem.

\section{Ancient Monuments Boards}

THe eighth annual reports of the Ancient Monuments Boards for England, Scotland and Wales contain much of interest in addition to the usual formal information ( $\mathrm{Pp} .19+4$ plates. London: H.M.S.O., 1962. 2s. net). The difficultios oncountored in draining the land at Stonehenge are discussed, but as yet no solution has been found. It is stressed that it is desirable to retain the turf which provides such an admirable setting for the stones. It is now recommended to the Minister that, because of irresponsible behaviour, there should bo an absolute ban on the solstice ceremonies on Midsummer Eve. It is proposed that the long barrow known as Wayland's Smithy in Borkshiro should be examined by modern techniques, and it is reported that tho Hull Museum is willing to take over and re-display the important pavement at the Roman villa at Rudstone. It is hoped that means will be found to preserve the somewhat unusual seventeenth century water garden at Wostbury-on-Severn, Gloucestershire, and the Board welcomes the action of the Council for British Archrology in their endeavours to preserve and rocord oarly industrial buildings. Reference is made to emergency excavations including that of the Saxon and medieval palace at Cheddar, and recommendations for scheduling are made in respect of 340 monuments. The report for Scotland refers to the continual quarrying at Traprain Law and the great interest of the Orkney monuments. The Board in Wales have recommended the scheduling of a further 31 monuments, several of which have only been discovered by aerial photography.

\section{The Museums Association}

Tre sixty-eighth annual conference of the Museums Association was held in London and Brussels during June 25-29 under the presidency of Dr. Mary Woodall. The presidential address and the annual general meeting were held in London, and the delegates then travelled to Brussels for the rest of the meeting. In her address, Dr. Mary Woodall dealt with presentday matters in the business of the Association and made especial reference to the importance of the 